\title{
A pilot study on using chlorine dioxide gas for disinfection of gastrointestinal endoscopes ${ }^{*}$
}

\author{
Ying $\mathrm{YI}^{\S 1}$, Li-mei $\mathrm{HAO}^{\S 1}$, Shu-ren $\mathrm{MA}^{2}$, Jin-hui $\mathrm{WU}^{1}$, Tao WANG ${ }^{1}$, \\ Song $\mathrm{LIN}^{1}$, Zong-xing ZHANG ${ }^{1}$, Jian-cheng $\mathrm{QI}^{\dagger+1}$ \\ ('Institute of Medical Equipment, Academy of Military Medical Sciences, Tianjin 300161, China) \\ ( ${ }^{2}$ Department of Digestive Endoscopy, General Hospital of Shenyang Military Region, Shenyang 110840, China) \\ ${ }^{\dagger}$ E-mail: qijch@npec.org.cn \\ Received Dec. 28, 2015; Revision accepted Mar. 22, 2016; Crosschecked June 18, 2016
}

\begin{abstract}
Objectives: This pilot study of employing chlorine dioxide (CD) gas to disinfect gastrointestinal endoscopes was conducted to meet the expectations of many endoscopy units in China for a high-efficiency and low-cost disinfectant. Methods: An experimental prototype with an active circulation mode was designed to use CD gas to disinfect gastrointestinal endoscopes. One type of testing device composed of polytetrafluoroethylene (PTFE) tubes ( $2 \mathrm{~m}$ long, inner diameter $1 \mathrm{~mm}$ ) and bacterial carrier containers was used to simulate the channel of the endoscope. PTFE bacterial carriers inoculated with Bacillus atrophaeus with or without organic burden were used to evaluate the sporicidal activity of $C D$ gas. Factors including exposure dosage, relative humidity $(\mathrm{RH})$, and flow rate $(\mathrm{FR})$ influencing the disinfection effect of $C D$ gas were investigated. Moreover, an autoptic disinfecting test on eight real gastrointestinal endoscopes after clinical use was performed using the experimental prototype. Results: $\mathrm{RH}$, exposure dosage, organic burden, and the FR through the channel significantly $(P<0.05)$ affected the disinfection efficacy of $\mathrm{CD}$ gas for a long and narrow lumen. The log reduction increased as FR decreased. Treatment with $4 \mathrm{mg} / \mathrm{L} \mathrm{CD} \mathrm{gas} \mathrm{for} 30 \mathrm{~min}$ at $0.8 \mathrm{~L} / \mathrm{min} \mathrm{FR}$ and $75 \% \mathrm{RH}$, resulted in complete inactivation of spores. Furthermore, all eight endoscopes with a maximum colony-forming unit of 915 were completely disinfected. The cost was only 3 CNY (0.46 USD) for each endoscope. Conclusions: The methods and results reported in this study could provide a basis for further studies on using $\mathrm{CD}$ gas for the disinfection of endoscopes.
\end{abstract}

Key words: Bacillus atrophaeus, Chlorine dioxide, Gaseous disinfectant, Gastrointestinal endoscope, Long and narrow channel

http://dx.doi.org/10.1631/jzus.B1500327

CLC number: $\mathrm{R} 187+.2$

\section{Introduction}

As one of the widely used semi-critical items in clinics, a gastrointestinal (GI) endoscope must go through high-level disinfection (HLD) before its next

\footnotetext{
\$Corresponding author

$\S$ The two authors contributed equally to this work

* Project supported by the National High-Tech R \& D Program (863) of China (No. 2014AA021405)

\# Electronic supplementary materials: The online version of this article (http://dx.doi.org/10.1631/jzus.B1500327) contains supplementary materials, which are available to authorized users

(ib) ORCID: Ying YI, http://orcid.org/0000-0001-8419-8875

(C) Zhejiang University and Springer-Verlag Berlin Heidelberg 2016
}

use to ensure medical safety (Petersen et al., 2011). Most endoscopy units in China have used glutaraldehyde (GA) as the preferred disinfectant, which has been proven to be ineffective against Mycobacterium chelonae and harmful to the staff involved in reprocessing endoscopes (Zhang et al., 2011). Other choices might include electrolyzed acid water (EAW), peracetic acid (PAA), and ortho-phthaldehyde (OPA). Application experience has shown that EAW and PAA are likely to result in damage to GI endoscopes. Although OPA was considered as the best alternative to GA, the cost of OPA is prohibitive, at nearly $40 \mathrm{CNY}$ (6.20 USD) for each endoscope (Medivator 
reprocessor with Cidex OPA). Thus, few Chinese endoscopy units have switched to OPA (Zhang et al., 2011). Therefore, many endoscopy units have high expectations for new approaches of HLD in delivering effective disinfection of GI endoscopes at a much lower cost.

To meet these demands, we conducted a pilot study on the use of chlorine dioxide (CD) gas for disinfection of GI endoscopes. CD gas is a registered sterilant that is approved by the United States Environmental Protection Agency (US EPA) and can kill almost all microorganisms, including vegetative forms of bacteria, bacterial spores, fungi, bacillus, and viruses (US EPA, 2006). It has already been widely employed to sterilize pharmaceutical facilities (Eylath et al., 2003a; 2003b), sanitize fruits (Jin et al., 2011), and vegetables (Park and Kang, 2015b), as well as to decontaminate several types of enclosed spaces, such as hospital rooms (Lowe et al., 2013a; 2013c), ambulances (Lowe et al., 2013b), biosafety laboratories (Wang et al., 2015), and associated devices (Luftman et al., 2008). Moreover, CD gas has been approved and is not carcinogenic, teratogenic, or mutagenic, and does not corrode stainless steel (316SS, 304SS), commonly used polymers or optical lenses (Kowalski, 1998; US EPA, 2010). In addition, because of its diffusion characteristics, CD gas is capable of decontaminating multiple devices with complex structures at one time. Therefore, it is very likely that CD gas can be applied to HLD of GI endoscopes.
Nonetheless, unlike the surfaces which have been tested in former studies (US EPA, 2004; Li et al., 2012), a GI endoscope contains long and narrow polytetrafluoroethylene (PTFE) channels. So it is important to determine how to disinfect the inner surfaces of such channels using $\mathrm{CD}$ gas and to study the factors that may affect the efficacy of disinfection.

\section{Materials and methods}

\subsection{Experimental prototype of a GI endoscope disinfector using CD gas}

Fig. 1 presents an experimental prototype that was designed and manufactured by our lab. Its main component is an air-tight chamber (width $\times$ depth $\times$ height, $500 \mathrm{~mm} \times 650 \mathrm{~mm} \times 800 \mathrm{~mm}$ ) that is connected to other functional modules. A generator $(\mathrm{Wu}$ et al., 2012) using the gas-solid method produces $C D$ gas in situ. An electrical heating humidifier is used to adjust the relative humidity ( $\mathrm{RH})$. While the $\mathrm{CD}$ gas is being discharged from the chamber by the exhaust fan, it is absorbed by a scrubber and the fresh air supplied to the chamber is purified by a high efficiency particulate air filter (HEPA). Up to eight GI endoscopes or testing devices arranged in the chamber can be connected to a confluence. A float flowmeter is set between the confluence and a circulation pump to adjust and monitor the total flow rate (FR) through all channels to the GI endoscopes or testing devices.

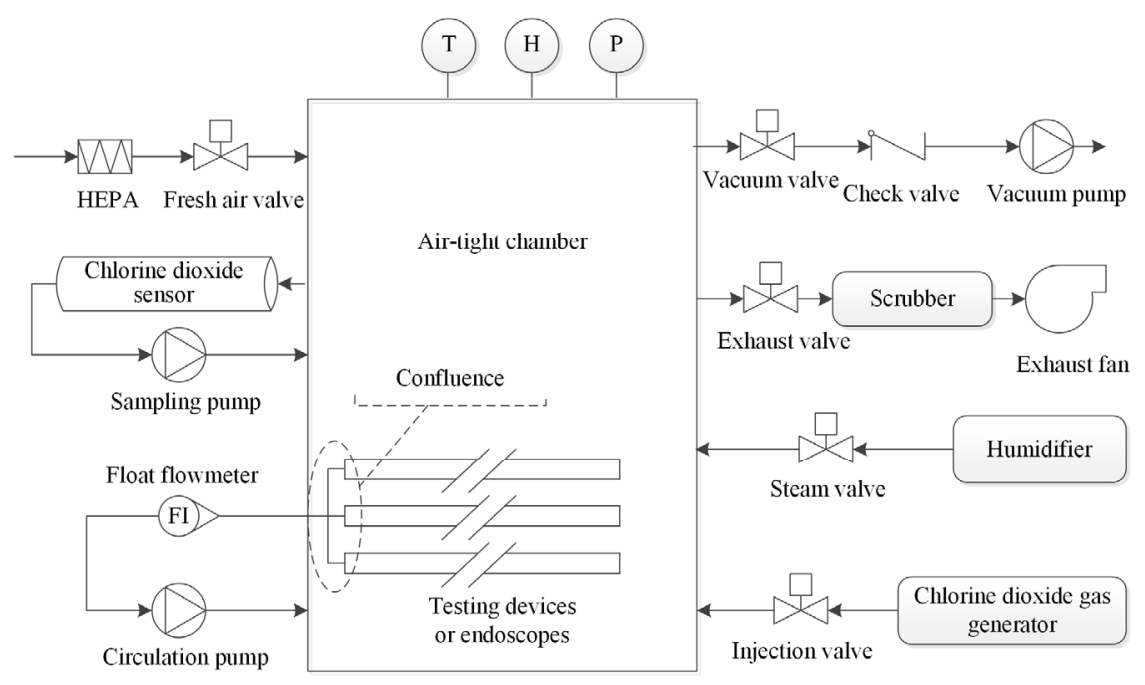

Fig. 1 Schematic diagram showing the structure of the experimental set-up

T: temperature sensor; H: relative humidity sensor; P: differential pressure sensor; HEPA: high efficiency particulate air filter 
Driven by the circulation pump, the gas re-enters the chamber after being flushed through the channels of the GI endoscopes or testing devices, confluence, flowmeter, and circulation pump. A CD gas sensor (AF26 sensor and C4000 controller; Optek-Danulat, Germany), a differential pressure sensor (DMP331P, $\mathrm{BD} \mid \mathrm{SENSORS}$, Germany), and a humidity and temperature sensor (HMD60Y, Vaisala, Finland) are configured to monitor the corresponding parameters in the chamber in real time.

\subsection{Testing device resembling the internal channel of a GI endoscope}

Fig. 2 shows the schematic structure of a testing device simulating the internal channel of an endoscope. Two 10-cm-long and two 90-cm-long PTFE tubes (inner diameter $1 \mathrm{~mm}$ ) were joined by fluorubber tubes and 4-cm-long straight fittings (inner diameter $2.4 \mathrm{~mm}$ ). Three bacterial carriers (BCs) were arranged in these three straight fittings to indicate the disinfection efficiencies of CD gas flow in the inlet, middle, and outlet sections of the PTFE channel. The PTFE tubes, fluorubber tubes, and straight fittings were treated by a degreasing process and were autoclaved for sterilization before application.

\subsection{Bacterial preparation and carrier inoculation}

About $2.3 \times 10^{8}$ colony-forming units (CFUs) per milliliter of spore suspension of Bacillus atrophaeus (ATCC 9372; China Center of Industrial Culture Collection, China) were prepared according to the Technical Standard for Disinfection (2002 Edition, China). Also, about $4.1 \times 10^{8} \mathrm{CFU} / \mathrm{ml}$ of spore suspensions of $B$. atrophaeus with $0.3 \%(3 \mathrm{~g} / \mathrm{L})$ and $3 \%$ $(0.03 \mathrm{~g} / \mathrm{ml})$ organic burden (Bovine Serum Albumin-
Fraction V (BSA-V), Roche, Switzerland) were prepared, respectively.

The spore suspension $(10 \mu \mathrm{l})$ with or without organic burden was evenly smeared onto each bacterial carrier (PTFE slice, $30 \mathrm{~mm}$ by $2 \mathrm{~mm}$ ) with a pipette. All carriers with the suspension were placed on plates in a Class II biological safety cabinet (BSC) for $1 \mathrm{~h}$ to dry before use. The prepared bacterial carriers were used within $24 \mathrm{~h}$ of inoculation.

\subsection{Disinfection process in the experimental prototype}

In this study, three testing devices with bacterial carriers were arranged in the chamber and connected to the confluence. Three other bacterial carriers, representing the outer surface of the GI endoscope, were placed in a sterilized plate inside the chamber. Another bacterial carrier was retained as a positive control in the Class II BSC. The total FR through these three testing devices was adjusted by the float flowmeter to the set value. One disinfection cycle was subsequently conducted in four steps: (1) pre-conditioning, turn on the vacuum pump until the relative pressure in the chamber reaches $-25 \mathrm{kPa}$; (2) conditioning and charging, activate the humidifier and generator until the $\mathrm{RH}$ and concentration of $\mathrm{CD}$ gas reach the set-points; (3) disinfection, expose the testing devices to $\mathrm{CD}$ gas until the set disinfection time has elapsed; (4) aeration, remove the $\mathrm{CD}$ gas by ventilation and absorption. In addition, the sampling and circulation pumps are switched on at the beginning of steps (2) and (3), respectively, and switched off at the end of the cycle. After the disinfection cycle, the testing devices were wrapped in sterilized aluminum foil and transferred into a Class II BSC. The bacterial carriers

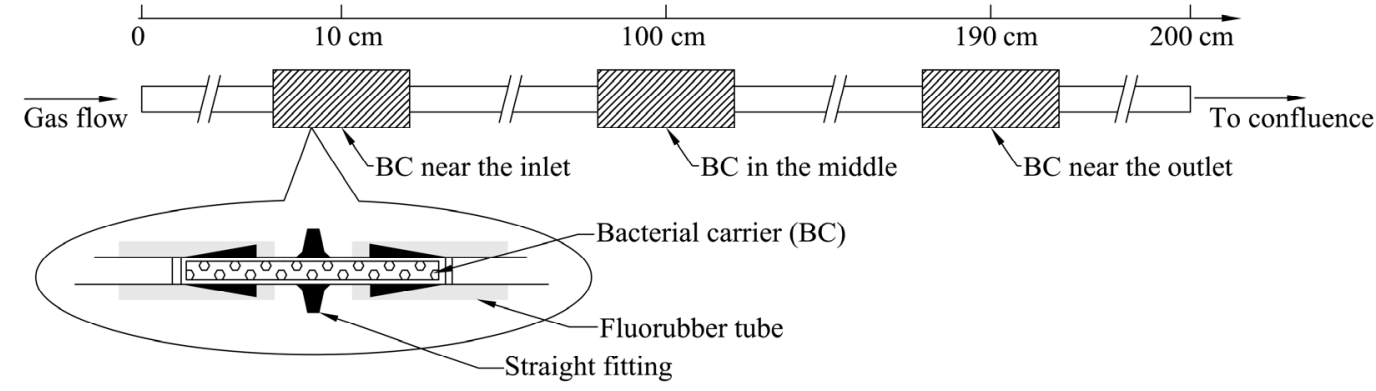

Fig. 2 Schematic diagram showing the structure of the testing device 
were taken out one by one for spore extraction. Each experiment was carried out three times.

\subsection{Spore extraction and culture}

Each bacterial carrier was transferred into a sterile tube with $10 \mathrm{ml}$ of sterilized extraction liquid ( $0.03 \mathrm{~mol} / \mathrm{L}$ phosphate-buffered saline, $0.85 \%(8.5 \mathrm{~g} / \mathrm{L})$ $\mathrm{NaCl}, 0.1 \%(1 \mathrm{~g} / \mathrm{L})$ Tween-80, $1 \%(0.01 \mathrm{~g} / \mathrm{ml})$ peptone, and $\left.1 \%(0.01 \mathrm{~g} / \mathrm{ml}) \mathrm{Na}_{2} \mathrm{~S}_{2} \mathrm{O}_{3}\right)$ and was then vortexed for $1 \mathrm{~min}$ at a speed of $1000 \mathrm{r} / \mathrm{min}$. Subsequently, the extraction liquid was aliquoted in a 10 -fold serial dilution, and then $1 \mathrm{ml}$ of $10^{3}$ and $10^{4}$ dilutions for the control carriers and $1 \mathrm{ml}$ of $10^{0}, 10^{1}$, and $10^{2}$ dilutions for the disinfected carriers were spread on nutrient broth agar plates (duplicate plates). These plates were incubated for $48 \mathrm{~h}$ at $37{ }^{\circ} \mathrm{C}$, and then the CFUs were recorded. The disinfection efficacy results are expressed as follows:

$\log$ reduction $=\log \left(N_{0} / N\right)$,

where $N_{0}$ and $N$ represent the CFUs recovered from disinfected and control carriers, respectively.

\subsection{Statistical analysis}

SAS Statistics software (Version 9.1.3, SAS Institute Inc., USA) was used for analysis of variance (ANOVA) of the experimental data. $P$-values of less than 0.05 were considered to be statistically significant.

\subsection{Autoptic experiment of disinfecting GI endo- scopes with the experimental prototype}

Verification of the disinfection effect of CD gas in real GI endoscopes was performed. Six gastroscopes (GIF-Q260, Olympus, Japan) and two colonoscopes (CF-Q260AI, Olympus, Japan) were simultaneously treated in the experimental prototype (Figs. S1 and S2) after clinical operation, pre-cleaning, manual cleaning, sampling, and blow-drying. For all of the treated endoscopes, the suction cylinder, air/ water cylinder, biopsy port, air supply connector, water supply connector, and electrical connector were sealed with matching accessories, and the suction connector and air pipe were connected to the branch connectors of the confluence (Fig. S3). Before and after disinfection using $\mathrm{CD}$ gas, samples were taken from the suction cylinder, air/water cylinder, biopsy port, and biopsy channel. Ten milliliters of eluent (0.03 mol/L phosphate-buffered saline and $1 \%$ $\left.(0.01 \mathrm{~g} / \mathrm{ml}) \mathrm{Na}_{2} \mathrm{~S}_{2} \mathrm{O}_{3}\right)$ were flushed through the biopsy channel using a 10-ml syringe and collected into a sterile tube from the distal end of the endoscope. For the other three samples, three sterile swabs wetted with sterile extraction liquid were used to swab the inner walls, and then their heads were cut into three tubes with $5 \mathrm{ml}$ of sterile extraction liquid. The tubes with samples were vortexed for $1 \mathrm{~min}$ at a speed of $1000 \mathrm{r} / \mathrm{min}$, and then $1 \mathrm{ml}$ of extraction liquid was spread on the bacterial count test pieces (duplicate pieces, Filmplate ${ }^{\mathrm{TM}}$ Aerobic BB202, Oasis Biochemical Tech., Guangzhou, China). The CFUs were recorded after these test pieces were incubated for $48 \mathrm{~h}$ at $37^{\circ} \mathrm{C}$.

Note that the upper and lower GI endoscopes must be disinfected separately in the practical operation. Putting the gastroscopes and the colonoscopes together in the process of the autoptic experiment was done to test the disinfection efficiency of $\mathrm{CD}$ gas on different GI endoscopes with different lengths and inner diameter channels. All eight endoscopes treated with $\mathrm{CD}$ gas were reprocessed according to guidelines using an automated endoscope reprocessor (AER; DSD-201, Medivator, USA) with OPA to ensure clinical safety.

\section{Results}

\subsection{Disinfection efficiencies of $C D$ gas with vari- ous RHs}

Fig. 3 shows the log reduction of spores on bacterial carriers treated with $5.6 \mathrm{mg} / \mathrm{L} \mathrm{CD}$ gas for $30 \mathrm{~min}$ with an FR of $4.6 \mathrm{~L} / \mathrm{min}$ and various RHs $(55 \%-85 \%)$. In general, the disinfection efficiency of $\mathrm{CD}$ gas for bacterial carriers in the same position increased as the RH increased $(P<0.05)$, and the log reductions of spores on bacterial carriers in the plates inside the chamber were greater than those in the testing devices. Also, for the bacterial carriers in each testing device, the log reduction of spores on the carrier near the inlet side was the largest, while that near the outlet was the smallest. When the RH was greater than $75 \%$, the spores on the bacterial carriers in the plates inside the chamber were completely inactivated. 


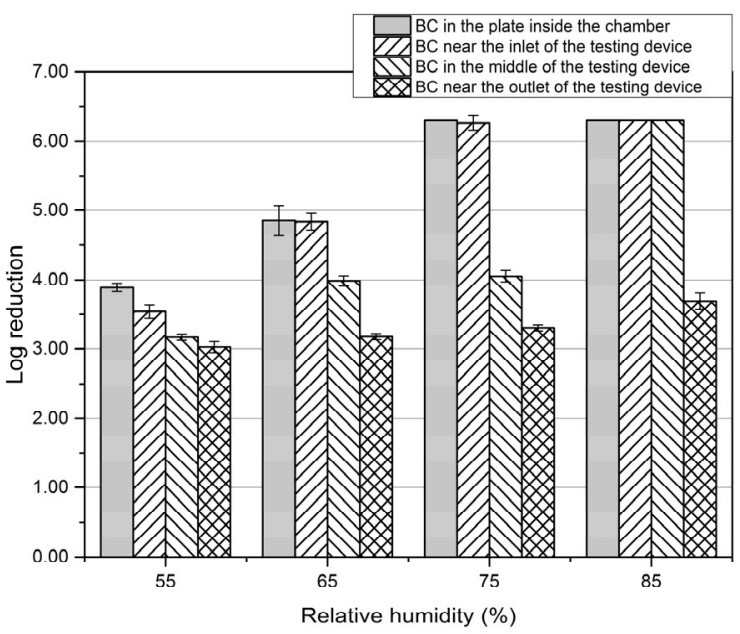

Fig. $3 \mathrm{Log}$ reductions of spores on bacterial carriers in the plates and testing devices treated with $5.6 \mathrm{mg} / \mathrm{L} \mathrm{CD}$ gas for 30 min with an FR of $4.6 \mathrm{~L} / \mathrm{min}$ and various RHs $(55 \%-85 \%)$ BC: bacterial carrier. The means and standard deviations were from nine replications (three parallel samples per experiment and three sets of experiments). The means of the log reductions with various RHs are significantly different $(P<0.05)$

\subsection{Disinfection efficiencies of $C D$ gas with vari- ous FRs}

The log reductions of spores on bacterial carriers following the $30 \mathrm{~min}$ treatment with $5.6 \mathrm{mg} / \mathrm{L} \mathrm{CD}$ gas, $75 \% \mathrm{RH}$, and various FRs $(0.8-4.6 \mathrm{~L} / \mathrm{min})$ are shown in Fig. 4. As the FR decreased, the inactivation of spores on bacterial carriers in the testing devices increased. When treated with an FR of $0.8 \mathrm{~L} / \mathrm{min}$, by passing about $0.27 \mathrm{~L} / \mathrm{min}$ through each testing device, all of the bacterial carriers, both in the plates and in the testing devices, were thoroughly sterilized.

\subsection{Disinfection efficiencies of $C D$ gas at various exposure dosages}

Four levels of exposure dosage (CD concentration multiplied by exposure time, $\mathrm{h} \cdot \mathrm{mg} / \mathrm{L}$ ) were evaluated (Table 1).

Table 1 CD gas treatment dosages with different concentrations and exposure time

\begin{tabular}{ccc}
\hline $\begin{array}{c}\text { Concentration of CD gas } \\
(\mathrm{mg} / \mathrm{L})\end{array}$ & $\begin{array}{c}\text { Exposure time } \\
(\mathrm{min})\end{array}$ & $\begin{array}{c}\text { Exposure dosage } \\
(\mathrm{h} \cdot \mathrm{mg} / \mathrm{L})\end{array}$ \\
\hline 4.0 & 20 & 1.33 \\
5.6 & 20 & 1.87 \\
4.0 & 30 & 2.00 \\
5.6 & 30 & 2.80 \\
\hline
\end{tabular}

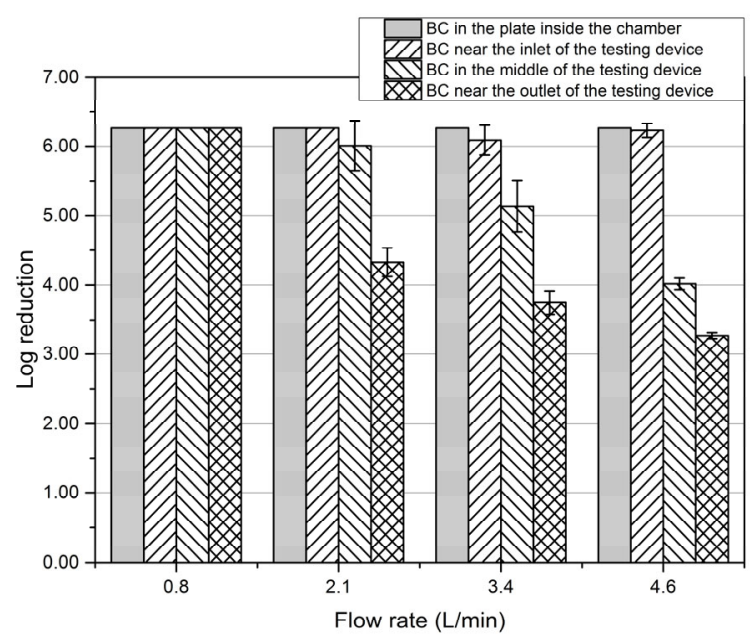

Fig. 4 Log reductions of spores on bacterial carriers in the plates and testing devices treated by $5.6 \mathrm{mg} / \mathrm{L} \mathrm{CD}$ gas for 30 min with $75 \% \mathrm{RH}$ and various FRs $(0.8-4.6 \mathrm{~L} / \mathrm{min})$

The FR is the total value through the three testing devices. BC: bacterial carrier. The means and standard deviations were from nine replications (three parallel samples per experiment and three sets of experiments). The means of the log reductions with various FRs are significantly different $(P<0.05)$

Fig. 5 shows the disinfection efficiency of CD gas in the inactivation of spores on the bacterial carriers with various exposure dosages, $75 \% \mathrm{RH}$ and $0.8 \mathrm{~L} / \mathrm{min}$ FR. Complete inactivation of spores was achieved when the exposure dosage was greater than $2.00 \mathrm{~h} \cdot \mathrm{mg} / \mathrm{L}$.

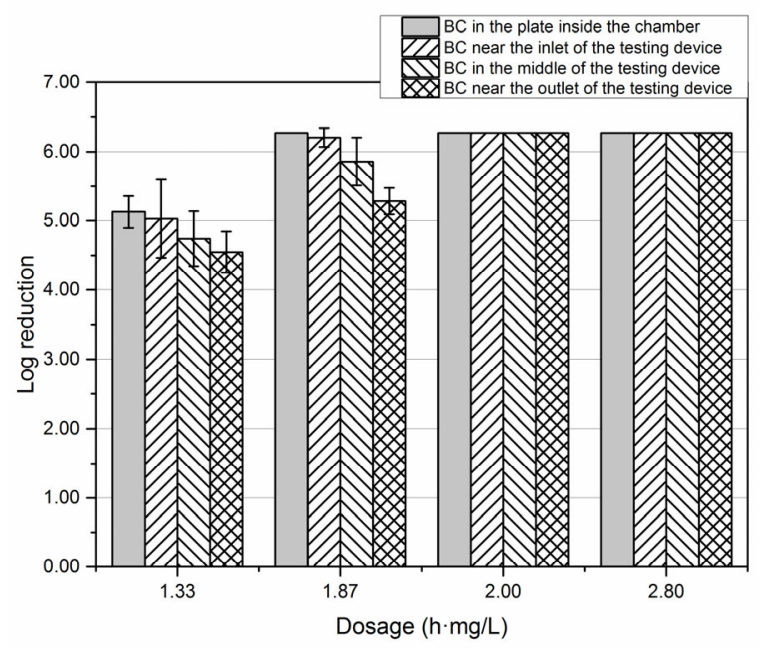

Fig. 5 Log reductions of spores on bacterial carriers in the plates and testing devices treated by various exposure dosages $(1.33-2.80 \mathrm{~h} \cdot \mathrm{mg} / \mathrm{L})$ with $75 \% \mathrm{RH}$ and $0.8 \mathrm{~L} / \mathrm{min} \mathrm{FR}$ BC: bacterial carrier. The means and standard deviations were from nine replications (three parallel samples per experiment and three sets of experiments). The means of log reductions with various exposure dosages are significantly different $(P<0.05)$ 


\subsection{Disinfection efficiency of CD gas on spores with or without organic burden}

Bacterial carriers contaminated with spores containing $0 \%, 0.3 \%$, and $3 \%(1 \%=0.01 \mathrm{~g} / \mathrm{ml})$ BSA were treated by $\mathrm{CD}$ gas under two experimental conditions (Table 2).

The results of $\log$ reductions of spores shown in Fig. 6 indicated that the disinfection efficiency of CD gas on spores was greatly weakened by organic burden. Disinfected by CD gas with the same parameters, spores without BSA on bacterial carriers were thoroughly killed, but spores with $0.3 \%$ BSA were killed only by $3.2 \log$ reductions. When the concentration of $\mathrm{CD}$ gas and the $\mathrm{RH}$ increased to $8 \mathrm{mg} / \mathrm{L}$ and $85 \%$, respectively, $>6 \log$ reductions of spores with $0.3 \%$ BSA were obtained.

\subsection{Autoptic experiment of disinfecting GI endo- scopes with the experimental prototype}

Table 3 shows the results of disinfecting the GI endoscopes with CD gas in the experimental prototype. After treatment with $5.6 \mathrm{mg} / \mathrm{L} \mathrm{CD}$ gas for $20 \mathrm{~min}$ with $75 \% \mathrm{RH}$ and a $2.4 \mathrm{~L} / \mathrm{min}$ total $\mathrm{FR}$, no viable bacteria were detected in the disinfected endoscopes.

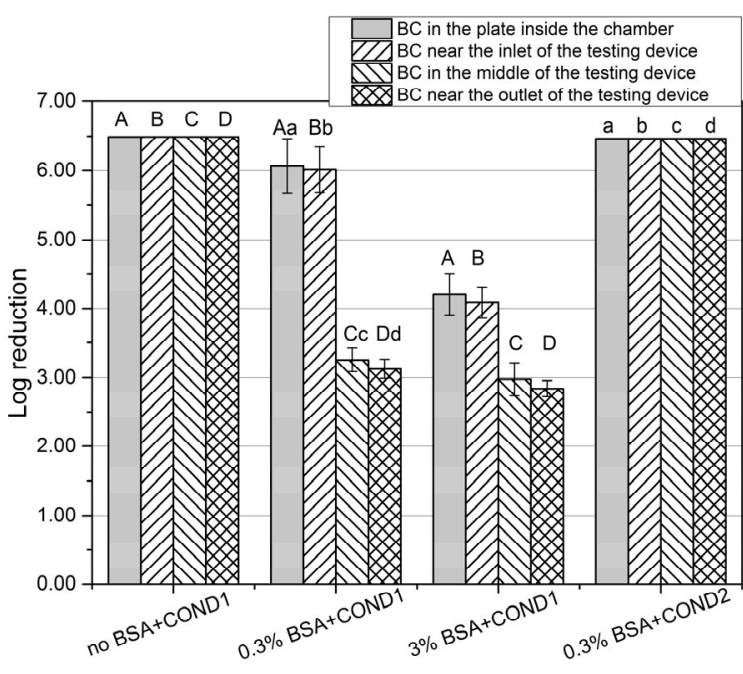

Fig. 6 Log reductions of spores with various concentrations of BSA on bacterial carriers in the plates and testing devices treated under two different conditions

COND1: $5.6 \mathrm{mg} / \mathrm{L} \mathrm{CD}$ gas for $30 \mathrm{~min}$ with $75 \% \mathrm{RH}$ and $0.8 \mathrm{~L} / \mathrm{min}$ FR. COND2: $8.0 \mathrm{mg} / \mathrm{L} \mathrm{CD}$ gas for $30 \mathrm{~min}$ with $85 \%$ $\mathrm{RH}$ and $0.8 \mathrm{~L} / \mathrm{min}$ FR. BC: bacterial carrier. The means and standard deviations were from nine replications (three parallel samples per experiment and three sets of experiments). The means of log reductions with the different uppercase or lowercase letters are significantly different $(P<0.05)$

Table 2 Concentration of BSA and CD gas treatment conditions

\begin{tabular}{cccccc}
\hline Group & $\begin{array}{c}\text { Concentration of } \\
\text { BSA }(\%)\end{array}$ & $\begin{array}{c}\text { Concentration of } \\
\text { CD gas }(\mathrm{mg} / \mathrm{L})\end{array}$ & $\begin{array}{c}\text { Exposure time } \\
(\mathrm{min})\end{array}$ & $\begin{array}{c}\text { Total flow rate } \\
(\mathrm{L} / \mathrm{min})\end{array}$ & $\begin{array}{c}\text { Relative humidity } \\
(\%)\end{array}$ \\
\hline 1 & 0 & 5.6 & 30 & 0.8 & 75 \\
2 & 0.3 & 5.6 & 30 & 0.8 & 75 \\
3 & 3 & 5.6 & 30 & 0.8 & 75 \\
4 & 0.3 & 8.0 & 30 & 0.8 & 85 \\
\hline
\end{tabular}

${ }^{*} 1 \%=0.01 \mathrm{~g} / \mathrm{ml}$

Table 3 Numbers of colonies counted from each sampling location of the endoscopes before and after disinfection using CD gas in the Department of Digestive Endoscopy, General Hospital of Shenyang Military Region, China

\begin{tabular}{|c|c|c|c|c|c|c|c|c|c|c|}
\hline \multirow{3}{*}{ No. } & \multirow{3}{*}{$\begin{array}{c}\text { Type of } \\
\text { endoscope }\end{array}$} & \multirow{3}{*}{$\begin{array}{l}\text { Serial No. of } \\
\text { endoscope }\end{array}$} & \multicolumn{8}{|c|}{ Number of colonies $(\mathrm{CFU})^{* *}$} \\
\hline & & & \multicolumn{2}{|c|}{ A } & \multicolumn{2}{|c|}{$\mathrm{B}$} & \multicolumn{2}{|c|}{$\mathrm{C}$} & \multicolumn{2}{|c|}{$\mathrm{D}$} \\
\hline & & & $\mathrm{BD}$ & $\mathrm{AD}$ & $\mathrm{BD}$ & $\mathrm{AD}$ & $\mathrm{BD}$ & $\mathrm{AD}$ & $\mathrm{BD}$ & $\mathrm{AD}$ \\
\hline 1 & GIF Q260 & 2150290 & 0 & 0 & 3 & 0 & 0 & 0 & 0 & 0 \\
\hline 2 & GIF Q260 & 2150292 & 0 & 0 & 0 & 0 & 68 & 0 & 25 & 0 \\
\hline 3 & GIF Q260 & 2857663 & 495 & 0 & 8 & 0 & 333 & 0 & 915 & 0 \\
\hline 4 & GIF Q260 & 2934941 & 0 & 0 & 0 & 0 & 0 & 0 & 0 & 0 \\
\hline 5 & GIF Q260 & 2150313 & 0 & 0 & 0 & 0 & 0 & 0 & 15 & 0 \\
\hline 6 & GIF Q260 & 2150282 & 13 & 0 & 0 & 0 & 0 & 0 & 70 & 0 \\
\hline 7 & CF Q260AI & 2814087 & 3 & 0 & 25 & 0 & 153 & 0 & 60 & 0 \\
\hline 8 & CF Q260AI & 2930389 & 43 & 0 & 0 & 0 & 0 & 0 & 105 & 0 \\
\hline
\end{tabular}

*All eight endoscopes treated with CD gas were reprocessed according to guidelines using an automated endoscope reprocessor (DSD-201, Medivator, USA) with OPA to ensure clinical safety. ${ }^{* *}$ The sampling location of the endoscope: A, suction cylinder; B, air/water cylinder;

C, biopsy port; D, biopsy channel. BD: before disinfection; AD: after disinfection 


\section{Discussion}

The complex structure of GI endoscopes poses a challenge for thorough cleaning and HLD (Ribeiro and Oliveira, 2012; Ofstead et al., 2015). More seriously, some pathogens including Pseudomonas aeruginosae (Qiu et al., 2015) and M. abscessus (de Groote et al., 2014) show resistance to GA and OPA. Recently, outbreaks of superbugs in the United States and other countries associated with GI endoscopes ignited concerns about shifting endoscope reprocessing from HLD to sterilization or improving the margin of safety (Edmiston and Spencer, 2014; Rutala and Weber, 2014). Extending disinfection time may be an effective approach, but it will increase the cost of disinfectants, which is a problem for endoscopy units in developing countries. Another way is to develop new endoscope reprocessing technologies. $\mathrm{CD}$ gas may be a reliable choice. Unlike liquid CD solutions, which have been applied to disinfect GI endoscopes and have been criticized because of their corrosiveness, CD gas has good material compatibility. In the present study, we designed and tested an experimental prototype which used CD gas for disinfection of GI endoscopes. An active circulation mode using a pump, similar to an AER but different from other gas sterilizers, such as low-temperature hydrogen peroxide gas plasma (LTHPGP), lowtemperature steam with formaldehyde (LTSF), and ethylene oxide (EtO) sterilizers, was designed to drive $\mathrm{CD}$ gas through the long and narrow channel to disinfect its inner surface and accelerate the removal of the residuals after disinfection.

\subsection{Comparison of CD gas method with other methods}

If eight GI endoscopes are treated with $5.6 \mathrm{mg} / \mathrm{L}$ $\mathrm{CD}$ gas for $20 \mathrm{~min}$ in the experimental prototype, a disinfection cycle can be completed within $30 \mathrm{~min}$ and costs only about $20 \mathrm{CNY}$ for consumable materials ( $2 \%$ chlorine gas and technical grade sodium chlorite, China). So it costs less than $3 \mathrm{CNY}$ for each endoscope, which is much cheaper than using OPA at nearly $40 \mathrm{CNY}$ per endoscope (CIDEX OPA). Both the $\mathrm{CD}$ gas disinfector and EtO gas sterilizer can process more endoscopes than AER with liquid chemical disinfectant, but the EtO sterilization cycle is 10-h long. So EtO is not suitable for the daily disinfection of GI endoscopes. A CD gas disinfector has advantages of low-cost, large processing capacity, and real-time concentration monitoring (Table 4).

However, it should be noted that the endoscope reprocessing using $\mathrm{CD}$ gas is different from that using a liquid chemical disinfectant, but is similar to that of an EtO sterilizer. Using $\mathrm{CD}$ gas, the reprocessing procedure was designed as follows: pre-cleaning, leak testing, manual washing and brushing, rinsing, drying, and disinfection of the endoscopes (Fig. 7). After manual washing and rinsing, cleaning and rinsing are repeated in an AER cycle to remove organic residues further. In the $\mathrm{CD}$ gas procedure, the manual washing and brushing step should be more carefully carried out to remove organic residues which can weaken the disinfection effect of a gaseous disinfectant. Also, the drying step is shifted between rinsing and the disinfection cycle to avoid corrosion by the $\mathrm{CD}$ solution

Table 4 Comparison of different reprocessing methods

\begin{tabular}{|c|c|c|c|c|c|}
\hline Method & $\begin{array}{l}\text { Maximum } \\
\text { endoscopes } \\
\text { per cycle }\end{array}$ & $\begin{array}{l}\text { Cycle } \\
\text { time } \\
(\min )^{*}\end{array}$ & $\begin{array}{c}\text { Cost per } \\
\text { endoscope } \\
(\mathrm{CNY})\end{array}$ & $\begin{array}{c}\text { Level of } \\
\text { disinfection }\end{array}$ & Monitoring of disinfectant \\
\hline AER with $2 \%$ GA & 2 & $35-45$ & 9 & HLD & $\begin{array}{c}\text { Test by strip every day (replaced } \\
\text { after } 14 \mathrm{~d} \text { or } 40 \text { endoscopes) }\end{array}$ \\
\hline AER with $0.55 \%$ OPA & 2 & $20-30$ & 40 & HLD & $\begin{array}{l}\text { Test by strip every day (replaced } \\
\text { after } 14 \mathrm{~d} \text { or } 60 \text { endoscopes) }\end{array}$ \\
\hline EtO sterilizer & $5^{* *}$ & 600 & 40 & Sterilization & Real-time monitoring \\
\hline $\begin{array}{l}\text { CD gas disinfector in } \\
\text { this study }\end{array}$ & 8 & 30 & $3 / 4^{\#}$ & HLD & Real-time monitoring \\
\hline
\end{tabular}




\begin{tabular}{|c|c|c|c|c|c|c|c|}
\hline$A$ & $\begin{array}{c}\text { Pre- } \\
\text { cleaning }\end{array}$ & Leak lesting & $\begin{array}{l}\text { Manual washing } \\
\text { and brushing }\end{array}$ & Rinsing & $\begin{array}{l}\text { Manual } \\
\text { soaking }\end{array}$ & $\begin{array}{l}\text { Final } \\
\text { rinsing }\end{array}$ & Drying \\
\hline$B$ & $\begin{array}{c}\text { Pre- } \\
\text { cleaning }\end{array}$ & $\begin{array}{l}\text { Leak testing } \\
\text { or in AER cycle }\end{array}$ & $\begin{array}{l}\text { Manual washing } \\
\text { and brushing }\end{array}$ & Rinsing & \multicolumn{2}{|c|}{ AER cycle } & Drying \\
\hline & & & $\begin{array}{l}\text { Leak testing } \\
\text { or by manual }\end{array}$ & Cleaning & Rinsing & Disinfection & $\begin{array}{l}\text { Final } \\
\text { rinsing }\end{array}$ \\
\hline C & $\begin{array}{c}\text { Pre- } \\
\text { cleaning }\end{array}$ & $\begin{array}{l}\text { Leak testing or } \\
\text { in (D) gas cycle }\end{array}$ & $\begin{array}{l}\text { Manual washing } \\
\text { and brushing }\end{array}$ & Rinsing & Drying & \multicolumn{2}{|c|}{$\begin{array}{c}\text { CD gas disinfection } \\
\text { cycle }\end{array}$} \\
\hline
\end{tabular}

Fig. 7 Reprocessing procedures with different methods

The background shaded steps indicate the main differences among the reprocessing procedures of manual, AER, and CD gas disinfectors. $A$ : manual reprocessing with a liquid chemical disinfectant; $B$ : AER with a liquid chemical disinfectant; $C$ : reprocessing with chlorine dioxide gas. AER: automated endoscope reprocessor; CD: chlorine dioxide

formed from $\mathrm{CD}$ gas dissolving in residual water. As a result, using $\mathrm{CD}$ gas for disinfecting GI endoscopes will increase the manual workload in the two steps of brushing and drying.

\subsection{Biological indicator organism}

To our knowledge, the spore form of Grampositive bacteria has the greatest resistance to chemical disinfectants among the different types of microorganisms, including Gram-negative and -positive bacteria, mycobacteria, viruses, and fungi. Thus, if a gaseous disinfectant is proven to be able to obtain a suitable $\log$ reduction of spores of Gram-positive bacteria, we would like to believe that it is also effective in deactivating all the other pathogens. As one of the most common spore-forming strains belonging to Gram-positive bacteria, B. atrophaeus has been widely used as a biological indicator for sterilization (Sella et al., 2015) and surface decontamination using formaldehyde gas, CD gas, and EtO gas. Disinfecting a GI endoscope involves decontaminating its inner and outer surfaces. Also, according to the Technical Standard for Disinfection (2002, China) and Technical Standard for Disinfection Effect Inspection of Automated Endoscope Reprocessor, Trial (2003, China), B. atrophaeus spores are required to be the biological indicator organism. So B. atrophaeus was the only indicator organism used in our study. Moreover, former studies have shown that $\mathrm{CD}$ gas is effective in inactivating various microorganisms including Geobacillus stearothermophilus (Luftman and Regits, 2008), M. smegmatis (Lowe et al., 2013c), Acinetobacter baumannii (Lowe et al., 2013c), methicillin-resistant Staphylococcus aureus (Lowe et al., 2013b), Escherichia coli (Mahmoud et al., 2008; Lowe et al., 2013c), and B. cereus spores in a biofilm (Nam et al., 2014).

\subsection{Factors influencing the disinfection efficacy of CD gas}

Previously published studies showed that exposure dosage and $\mathrm{RH}$ are the main factors influencing the disinfection efficacy of CD gas (Jeng and Woodworth, 1990; Park and Kang, 2015a). We obtained similar results in our study: the log reductions of spores became greater with increasing exposure dosage or RH. Furthermore, we found that the FR through the channel could also strongly impact the disinfection efficacy of $\mathrm{CD}$ gas when it was used to disinfect the long and narrow lumens. The disinfection efficacy at a low FR was significantly superior to that at a high FR. One possible reason for this observation may be as follows. Because PTFE is a type of air-proof hydrophobic material, a spore suspension will form a plaque of a certain thickness on the carrier when dry. A higher FR could reduce the probability of water molecules persisting on the spore plaque, consequently abating the chance of water molecules softening the spore wall. As a result, the ability of CD molecules to penetrate the spore wall and inactivate the spore will be weakened. The decrease in the log reduction of spores as the bacteria were carried away from the inlet of the testing device may also have occurred because of the change in the concentration of $\mathrm{CD}$ gas and RH while the gas flowed through the long and narrow channel. 
The sporicidal efficacy of CD gas was also adversely affected by organic burden. An evaluation of decontaminating enclosed space by CD gas (Jia et al., 2013) involving qualitative experiments indicated that both stainless and filter paper coupons contaminated by spores of $B$. subtilis var. niger without BSA were sterilized, while more than $66 \%$ of all coupons with $1 \%$ BSA failed, following treatment with $10^{-3}$ (v/v) CD gas for $4 \mathrm{~h}$ at $75 \% \mathrm{RH}$. Our study showed similar results. Under the same disinfection condition, if spore suspensions contained $0.3 \% \mathrm{BSA}$, the log reductions of spores decreased from 6.5 to 3.1. It is believed that CD gas primarily inactivates cell membranes but not the DNA of spores (Young and Setlow, 2003). Organic substances added in the spore suspension may wrap the spores and hinder the penetration of $\mathrm{CD}$. To enhance the penetration of $\mathrm{CD}$ into spores and improve the disinfection efficacy of $\mathrm{CD}$ gas on spores with protection from organic substances, effective means may include increasing the concentration of $\mathrm{CD}$ gas and the RH of the space. In our study, this was proven to be effective.

When applying CD gas to disinfect GI endoscopes, the influence of organic burden must be taken into account because contaminated GI endoscopes in real-life are commonly loaded with body fluids. Although $>3.1 \log$ reductions of spores with $0.3 \%$ BSA can be obtained, which meets the requirements of HLD, by using $5.6 \mathrm{mg} / \mathrm{L} \mathrm{CD}$ gas for 30 min with $75 \% \mathrm{RH}$ and $0.8 \mathrm{~L} / \mathrm{min} \mathrm{FR}$, it is better to consider more effective disinfection parameters to enlarge the medical safety margin.

\subsection{Limitations of this study}

Based on this paper, further tests should be implemented on the disinfection efficacy of CD gas with a testing device composed of multiple channels and right-angle turns, which is more similar to a GI endoscope. Also, more autoptic experiments, especially on the disinfection efficiency of $\mathrm{CD}$ gas against Clostridium difficile spores and aldehyde-resistant mycobacteria, should be carried out in future.

\section{Conclusions}

The experimental results indicated that disinfecting GI endoscopes using CD gas could reduce the cost of disinfectants while ensuring a high log reduc- tion of spores. Thus, CD gas may be a feasible choice for disinfection of GI endoscopes. Furthermore, this study provides information for decontaminating long and narrow lumens with gaseous sterilants.

\section{Compliance with ethics guidelines}

Ying YI, Li-mei HAO, Shu-ren MA, Jin-hui WU, Tao WANG, Song LIN, Zong-xing ZHANG, and Jian-cheng QI declare that they have no conflict of interest.

This article does not contain any studies with human or animal subjects performed by any of the authors.

\section{References}

de Groote, M.A., Gibbs, S., de Moura, V.C., et al., 2014. Analysis of a panel of rapidly growing mycobacteria for resistance to aldehyde-based disinfectants. Am. J. Infect. Control, 42(8):932-934. http://dx.doi.org/10.1016/j.ajic.2014.05.014

Edmiston, C.E.Jr., Spencer, M., 2014. Endoscope reprocessing in 2014: why is the margin of safety so small? AORN J., 100(6):609-615. http://dx.doi.org/10.1016/j.aorn.2014.10.011

Eylath, A., Madhogarhia, E., Rivera, E., et al., 2003a. Successful sterilization using chlorine dioxide gas: Part one-sanitizing as aseptic fill isolator. BioProcess Int., 1(7):52-55.

Eylath, A., Madhogarhia, E., Lorcheim, P., et al., 2003 b. Successful sterilization using chlorine dioxide gas: Part two - cleaning process vessels. BioProcess Int., 1(8):54-56.

Jeng, D.K., Woodworth, A.G., 1990. Chlorine dioxide gas sterilization under square-wave conditions. Appl. Environ. Microbiol., 56(2):514-519.

Jia, H.Q., Wu, J.H., Yi, Y., et al., 2013. Evaluation of gaseous chlorine dioxide fumigation for enclosed space decontamination. Mil. Med. Sci., 37(1):33-38 (in Chinese).

Jin, R.Y., Hu, S.Q., Chi, Z.C., 2011. Effect of chlorine dioxide gas treatment on surface sterilization of grape. Adv. Mater. Res., 236:2939-2944. http://dx.doi.org/10.4028/www. scientific.net/AMR.236-238.2939

Kowalski, J.B., 1998. Sterilization of medical devices, pharmaceutical components, and barrier isolator systems with gaseous chlorine dioxide. In: Morrissey, R.F., Kowalski, J.B. (Eds.), Sterilization of Medical Products. Polyscience Publications, New York, p.313-323.

Li, Y.J., Zhu, N., Jia, H.Q., et al., 2012. Decontamination of Bacillus subtilis var. niger spores on selected surfaces by chlorine dioxide gas. J. Zhejiang Univ.-Sci. B (Biomed. \& Biotechnol.), 13(4):254-260. http://dx.doi.org/10.1631/jzus.B1100289

Lowe, J.J., Gibbs, S.G., Iwen, P.C., et al., $2013 \mathrm{a}$. Decontamination of a hospital room using gaseous chlorine dioxide: Bacillus anthracis, Francisella tularensis, and Yersinia pestis. J. Occup. Environ. Hyg., 10(10): 533-539. http://dx.doi.org/10.1080/15459624.2013.818241 
Lowe, J.J., Hewlett, A.L., Iwen, P.C., et al., 2013b. Evaluation of ambulance decontamination using gaseous chlorine dioxide. Prehosp. Emerg. Care, 17(3):401-408. http://dx.doi.org/10.3109/10903127.2013.792889

Lowe, J.J., Gibbs, S.G., Iwen, P.C., et al., 2013c. Impact of chlorine dioxide gas sterilization on nosocomial organism viability in a hospital room. Int. J. Environ. Res. Public Health, 10(6):2596-2605. http://dx.doi.org/10.3390/ijerph10062596

Luftman, H.S., Regits, M.A., 2008. B. atrophaeus and G. stearothermophilus biological indicators for chlorine dioxide gas decontamination. Appl. Biosafety, 13(3): 143-157. http://dx.doi.org/10.1177/153567600801300304

Luftman, H.S., Regits, M.A., Lorcheim, P., et al., 2008. Validation study for the use of chlorine dioxide gas as a decontaminant for biological safety cabinets. Appl. Biosafety, 13(4):199-212. http://dx.doi.org/10.1177/153567600801300403

Mahmoud, B., Vaidya, N.A., Corvalan, C.M., 2008. Inactivation kinetics of inoculated Escherichia coli O157:H7, Listeria monocytogenes and Salmonella Poona on whole cantaloupe by chlorine dioxide gas. Food Microbiol., 25(7):857-865. http://dx.doi.org/10.1016/j.fm.2008.05.009

Nam, H., Seo, H.S., Bang, J., et al., 2014. Efficacy of gaseous chlorine dioxide in inactivating Bacillus cereus spores attached to and in a biofilm on stainless steel. Int. J. Food Microbiol., 188:122-127. http://dx.doi.org/10.1016/j.ijfoodmicro.2014.07.009

Ofstead, C.L., Wetzler, H.P., Doyle, E.M., et al., 2015. Persistent contamination on colonoscopes and gastroscopes detected by biologic cultures and rapid indicators despite reprocessing performed in accordance with guidelines. Am. J. Infect. Control, 43(8):794-801. http://dx.doi.org/10.1016/j.ajic.2015.03.003

Park, S.H., Kang, D.H., 2015a. Antimicrobial effect of chlorine dioxide gas against foodborne pathogens under differing conditions of relative humidity. LWT-Food Sci. Technol., 60(1):186-191. http://dx.doi.org/10.1016/j.lwt.2014.09.031

Park, S.H., Kang, D.H., 2015b. Combination treatment of chlorine dioxide gas and aerosolized sanitizer for inactivating foodborne pathogens on spinach leaves and tomatoes. Int. J. Food Microbiol., 207:103-108. http://dx.doi.org/10.1016/j.ijfoodmicro.2015.04.044

Petersen, B.T., Chennat, J., Cohen, J., et al., 2011. Multisociety guideline on reprocessing flexible gastrointestinal endoscopes: 2011. Gastrointest. Endosc., 73(6):1075-1084. http://dx.doi.org/10.1016/j.gie.2011.03.1183

Qiu, L.J., Zhou, Z.H., Liu, Q.F., et al., 2015. Investigating the failure of repeated standard cleaning and disinfection of a Pseudomonas aeruginosa-infected pancreatic and biliary endoscope. Am. J. Infect. Control, 43(8):e43-e46. http://dx.doi.org/10.1016/j.ajic.2015.04.204
Ribeiro, M., Oliveira, A., 2012. Analysis of the air/water channels of gastrointestinal endoscopies as a risk factor for the transmission of microorganisms among patients. Am. J. Infect. Control, 40(10):913-916. http://dx.doi.org/10.1016/j.ajic.2012.02.005

Rutala, W.A., Weber, D.J., 2014. Gastrointestinal endoscopes: a need to shift from disinfection to sterilization? JAMA, 312(14):1405-1406. http://dx.doi.org/10.1001/jama.2014.12559

Sella, S.R., Vandenberghe, L.P., Soccol, C.R., 2015. Bacillus atrophaeus: main characteristics and biotechnological applications-a review. Crit. Rev. Biotechnol., 35(4): 533-545. http://dx.doi.org/10.3109/07388551.2014.922915

US EPA, 2004. CDG research corporation bench-scale chlorine dioxide gas: solid generator. Technical Report No. EPA/600/R-11/199, ETV Building Decontamination Technology Center, US Environmental Protection Agency, Washington, D.C.

US EPA, 2006. Reregistration eligibility decision (RED) for chlorine dioxide and sodium chlorite (Case 4023). Technical Report No. EPA/738/R-06/007, Antimicrobials Division, US Environmental Protection Agency, Washington, D.C.

US EPA, 2010. Compatibility of material and electronic equipment with chlorine dioxide fumigation. Technical Report No. EPA/600/R-10/037, Office of Research and Development, US Environmental Protection Agency, New Caledonia.

Wang, Y.Q., Sun, L.Q., Liu, X.J., et al., 2015. Evaluation of disinfection effect of chlorine dioxide gas on biosafety levels-III laboratory. Chin. J. Disinfec., 32(1):13-15 (in Chinese).

Wu, J.H., Yi, Y., Jia, H.Q., et al., 2012. Effect of gaseous chlorine dioxide on disinfection of laboratory microenvironment. Chin. J. Nosocomiol., 22(2):331-334 (in Chinese).

Young, S.B., Setlow, P., 2003. Mechanisms of killing of Bacillus subtilis spores by hypochlorite and chlorine dioxide. J. Appl. Microbiol., 95(1):54-67. http://dx.doi.org/10.1046/j.1365-2672.2003.01960.x

Zhang, X.L., Kong, J.Y., Tang, P., et al., 2011. Current status of cleaning and disinfection for gastrointestinal endoscopy in China: a survey of 122 endoscopy units. Digest. Liver Dis., 43(4):305-308.

http://dx.doi.org/10.1016/j.dld.2010.12.010

\section{List of electronic supplementary materials}

Fig. S1 Appearance of the experimental prototype

Fig. S2 Six gastroscopes (GIF-Q260, Olympus, Japan) and two colonoscopes (CF-Q260AI, Olympus, Japan) to be disinfected in the experimental prototype

Fig. S3 Methods to seal and connect the opening ports of the GI endoscope 


\section{中文概要}

题 目: 应用二氧化氯气体消毒消化内镜的初步研究

目 的: 以大型消化内镜中心控制消化内镜消毒成本的需 求为牵引, 评价二氧化氯气体应用于消化内镜消 毒的可行性。

创新点: 首次研究了二氧化氯气体对细长管腔内部的消毒 效果及其影响因素, 并以此为基础研究了采用主 动灌流方法的二氧化氯气体消毒消化内镜的原 型机。

方 法: 设计了一种聚四氟乙烯 (PTFE) 细长管腔实验 装置（长 $2 \mathrm{~m}$, 内径 $1 \mathrm{~mm}$ ), 在其进气端、中 部和出气端分别设置 PTFE 菌片容器。将含有 PTFE 菌片和细长管腔和置于平皿内的 PTFE 菌 片装载于一种消毒实验原型机中, 通过主动灌流 使二氧化氯气体流过细长管腔, 平皿内的 PTFE 菌片直接曝露于二氧化氯气体中, 分别评价二氧
化氯气体对 PTFE 细长管腔内壁和外壁的消毒效 果。以萎缩芽狍杆菌为指示微生物, 评价二氧化 氯剂量（浓度与时间的乘积）、相对湿度、流过 细长管腔的流量及有机干扰物对消毒效果的影 响。同时使用实验原型机对 8 条消化内镜进行了 实效验证实验。

结 论: 实验结果表明, 除了相对湿度、二氧化氯剂量和 有机干扰物都显著影响二氧化氯气体的消毒效 果外 (图 3、5 和 6), 随着经过细长管腔流量的 增大, 二氧化氯气体对细长管腔内部的芽狍杀灭 对数值有减小的趋势（图 4)。按照本文设计的 流程, 应用实验原型机对 8 条消化内镜消毒后, 未检出存活的微生物。应用二氧化氯气体消毒消 化内镜时, 其每条内镜的消毒剂成本小于 3 元人 民币。

关键词: 二氧化氯; 气体消毒剂; 消化内镜; 细长管腔; 萎缩芽狍杆菌 